Article

\title{
Thomas Pogge and the Limits of Negative Duty
}

\section{Ian Clark R. Parcon}

\begin{abstract}
Thomas Pogge's philosophy on global justice is considered as a radical proposal that makes use of institutional, justice-based arguments from John Rawls and extends it to the global sphere that even Rawls is hesitant to undertake. This proposal of extending justice to the global sphere provides a more comprehensive grasp of the global poverty situation that takes into consideration not only factors at the nation-state level but also international agencies, international agreements, regional assemblies and other international actors. From the political philosophy's perspective, however, Rawls insist that his proposal only asserts a negative duty-based institutional approach. While this is a welcome proposal for many, especially for defenders of a liberal political philosophy, there are also those that have challenged the limitations of his negative duty-based approach as a strategy and as a philosophical response to global poverty. This paper will show that various critiques have misunderstood Pogge's proposal but some have also pushed his theory towards the positive duty-based dimension, which he does not deny but simply avoids as a matter of strategy. The argument here is that Pogge's global justice approach cannot escape the demand for positive duty especially as a demand of justice from citizens of affluent countries, and this is a very significant though underdeveloped aspect of his theory.
\end{abstract}

Keywords: Pogge, global poverty, global justice, negative and positive duty

\section{Introduction}

7 The prevalence of poverty at the global scale, which has brought 360 million related deaths for the past 20 years after the Cold War with 18 million added annually, is a significant cause of concern. ${ }^{1}$ It also poses

1 Thomas Pogge, Politics as Usual: What lies behind the pro-poor rhetoric (Cambridge: Polity Press, 2010), 11.

(C) 2017 lan Clark R. Parcon

http://www.kritike.org/journal/issue 20/parcon june2017.pdf

ISSN 1908-7330 
a challenge to various academic disciplines including philosophical and moral thinking on how to seriously understand and provide conditions for possibility that can create solutions to the problem. The challenge to philosophical thinking involves appropriate framework for analysis given that, as pointed out by Thomas Pogge, the usual framework that considers state factors as the root cause of poverty is no longer sufficient to explain the problem. ${ }^{2}$ Furthermore, the usual interactional moral analysis that ascribes explanations and solutions to individuals or collective actors is also insufficient. There are those, like John Rawls, that argue for an institutional mechanism in addressing fair distribution but are not so keen in applying the framework at the global scale. ${ }^{3}$ The concern on global poverty, which leads to the question on justice and just distribution, is a complex one that the statecentric framework is rendered limited.

It is in the context of the limitation of the state-centric approach that Thomas Pogge's institutional response provides a landmark proposal in the discourse on global justice by proposing not just state centric nor international affairs analysis but institutional analysis at the global scale. This proposal has altered the understanding of social justice in that it gives primacy to institutional structures in the analysis of global justice. What Pogge proposes is to assess global institutions as to how responsive they are in upholding the rights of the global poor. Pogge claims that the existing global structure is the primary reason for the prevalence of poverty and it is in altering the rules of the global order that significant solution can be given to the poverty problem. ${ }^{4}$

Pogge's claim, however, is that this proposal of upholding and protecting the rights of the global poor only demands negative duty especially to affluent countries that include the state and its citizens. This negative duty includes changes in the institutional structure so that it prevents harming the global poor. It is opposed to the aid strategy that gives direct assistance to those in conditions of poverty. This direct active intervention is considered as positive duty. ${ }^{5}$

\footnotetext{
${ }^{2}$ Ibid, 13-14.

${ }^{3}$ John Rawls, Theory of Justice (Massachusetts: Harvard University Press, 1971) and The Law of Peoples (Massachusetts: Harvard University Press, 1999). The limits of Rawls international justice proposal are also extensively discussed by Thomas Pogge in "Rawls on International Justice" in The Philosophical Quarterly, 51:203 (2001): 246-253, by pointing out that Rawls creates a dualism that is the application of institutional justice at the state level but not at the international or global level.

${ }^{4}$ Pogge, Politics as Usual, 10-25.

5 Thomas Pogge, World Poverty and Human Rights: Cosmopolitan Responsibilities and Reform (Cambridge: Polity Press, 2002), 52-70.
} 
It is important that discussion of rights needs a parallel discussion of duties. This is not just for purposes of philosophical reasoning but also for practical considerations. This is so since in the discourse on global poverty, it is important to identify not just who are affected by injustice, whose rights need to be protected but also who are responsible for the existence of poverty that need to respond to the problem. The notion of duty then is an important consideration in the discourse on global justice to identify those who are responsible for the injustice at the global scale and to identify also who are most responsible for responding to this problem.

It is in the given proposal of Pogge to address global poverty through the institutional negative duty-based moral demand of justice as opposed to the positive duty aid and direct assistance approach that we ask the question: Is negative duty enough? Is Pogge's proposal only limited to negative duty as he claims, and can his proposal be successful by founding it in negative duty alone? As a response to the question, I would assert that Pogge's institutional proposal is limited if it hinges on negative duty alone. More than the problematic argument for negative duty, global poverty cannot be fully remedied by claims of negative duty alone. I will further argue, however, that Pogge's institutional approach does not necessarily deny positive duty, but this aspect of his argument is underdeveloped. This paper would show that while greater responsibility lies on the affluent countries, including both their government and citizens, the responsibility is for everyone.

I would develop this thesis in three parts. First, I will discuss Pogge's moral position that argues for a negative duty-based institutional approach. This part will include extensive discussion on his understanding of global justice, human rights and its correlative duties as well as the claim to universality of this duty. Next, I will present various questions to Pogge's proposition that is grounded on negative duty. Critique and counterproposal are discussed by Cruft, Tan, Chandhoke, and Caney. Finally, I will provide a critical reflection that shows the area in Pogge's argument that can be further developed towards a greater possibility of positive duties that will provide a more comprehensive understanding of global justice.

\section{Pogge's Institutional Approach}

Thomas Pogge's pivotal proposal provides a significant leap in the discourse on global justice that for several centuries has been limited to justice at the national level or, at most, at the international level. What are usually discussed are the interactions of a state with another state, which is referred to as international relations. This involves the role of states in forging treatises and agreements with another state. This is more specifically discussed using the language of international justice or international ethics. This is a more 
advanced analysis from the explanatory nationalism, which anchors reasons for poverty on the internal structure of the state, which includes persistence of corruption, lack of transparency, and limited natural resources and human capabilities. ${ }^{6}$

The prevalence of poverty is also discussed in the context of ethics rather than justice. This means that we associate reasons for poverty with the direct cause, which includes individual or collective actors. However, following the principles invoked by Rawls, we have to pay closer attention to institutional matters as matters of justice, and matters related to the conduct and character of individuals or groups, as matters of ethics. Pogge also invoked an institutional approach in the analysis of global poverty and in the process argued for an institutional approach in the understanding of justice. ${ }^{7}$

Furthermore, it is important for Pogge to distinguish between the institutional and the interactional approach. The interactional approach points to actors, both individual and collective, as responsible for the existence of poverty. The institutional approach, however, does not do away with the interactional aspect but points to a bigger reality that includes institutions that are responsible for the persistence of poverty. ${ }^{8}$ The institution he refers to is the global order that must be primarily addressed for problems of poverty to be given solution.

The current set-up at the international level, however, is more complex than what is presented by explanatory nationalism and international relations. It is not only the internal state factors nor state-to-state relations that are responsible for the existence of poverty but also other actors in the field. In the recent analysis, multinational corporations as well as supranational bodies like IMF, EU, and World Bank have also been a significant factor in the existence and persistence of poverty. This complex reality, which Pogge would refer to as the global order, is responsible for poverty. ${ }^{9}$

Pogge points to this complex reality at the global level because of the growing interdependence of the aforementioned actors. The rising international agencies, which we have referred to as supranational bodies, interact with Multinational Corporations (MNCs) and Non-Governmental Organizations (NGOs). They also are party to the creation of rules, policies, treatise, and agreements that before, lie only on state-to-state relations. These policies are responsible for the flow of capital and resources that, for Pogge, are primarily responsible for the persistence of poverty at the global scale. ${ }^{10}$

\footnotetext{
${ }^{6}$ Pogge, Politics as Usual, 10-56.

${ }^{7}$ Ibid, 14-19.

8 Ibid, 14-15.

${ }^{9} \mathrm{Ibid}, 14$.

${ }^{10} \mathrm{Ibid}$.
}

(c) 2017 lan Clark R. Parcon

http://www.kritike.org/journal/issue 20/parcon june2017.pdf

ISSN 1908-7330 
Pogge would focus primarily on the global institutional order for it is this system that also perpetrates the poverty levels at the national level. It is also this global institutional order that must be addressed for global poverty to be significantly addressed. This is more properly elaborated by Pogge:

By breaking down the traditional separation of intranational and international relations and extending institutional moral analysis to the whole field, the concept of global justice also makes visible how citizens of affluent countries are potentially implicated in the horrors so many must endure in the so-called less developed countries: how global institutional arrangements they uphold are implicated in the violence and hunger that are inflicted upon the global poor. ${ }^{11}$

The timeliness of this moral claim that Pogge makes is striking because of the existence and persistence of global poverty on the one side of the globe while there is a growing sense of affluence in another part of the globe. This level of inequality is also widening in that the rich countries are getting richer and the poor countries are getting poorer. Finally, there is also to reiterate his institutional approach where the analysis would show that the growing global interdependence has led treatises, trade agreements, and schemes of supranational entities as also highly responsible for the existence of this global poverty. A more complex analysis of global justice, then, is needed. ${ }^{12}$

This persistence of global poverty, heightened by growing inequality, led Pogge to claim that there is significant harm done to the global poor so much so that it constitutes what he considers to be a violation of human rights. The institutional moral analysis he undertook generates the conclusion that injustice results from the violation of the rights of the global poor that is elaborated in the Universal Declaration of Human Rights (UNDHR). ${ }^{13}$

This claim to rights is discussed by Pogge while being mindful of the distinction and interrelation of legal human rights and moral human rights. His emphasis is on the latter in that it has a more universal claim. The former can be limited due to the differences in context like religion and culture where a legal formulation is developed and adopted. ${ }^{14}$

\footnotetext{
${ }^{11}$ Ibid, 19.

${ }^{12}$ Ibid, 12-13.

${ }^{13} \mathrm{Ibid}, 50-52$.

${ }^{14}$ Pogge, World Poverty and Human Rights, 54.
} 
He would further emphasize that moral demands are supposed to be unrestricted, that is, it should not be dependent on culture, religion, moral tradition, or philosophy. This means that rights have to be appreciated and recognized by everyone. It is his claim then that those espoused on the UNDHR are moral rights that should be afforded to everyone. His reference to the provisions in UNDHR makes Pogge ascribe to legal rights insofar as it is founded on a well-argued set of moral rights. The provisions in the UNDHR show the closer interrelationship of legal and moral human rights even if the latter has a more universal claim. UNDHR is a clear example where legal human rights are grounded on moral human rights. ${ }^{15}$

A better understanding of Pogge's notion of human rights is to understand his claim as appreciating the move from natural right to human rights. This is important since the notion of human rights, unlike natural right, is detached from the notion of historical antecedents like Medieval Christianity. In other words, what Pogge is proposing is highly secular. This is also further affirming the proposal of Rawls that these rights are political and not metaphysical. ${ }^{16}$ The strength of this argument, however, is due to the claim that these rights are universal primarily because it treats all human beings as equal and therefore they can be afforded the same set of rights as everyone else enjoys.

Pogge also referred to the violation of these human rights as official disrespect. This means that the violation of these rights is done by formal institutions like governments and states. Government, however, is referred to in broader terms to include also the other agencies that constitute this government, which also includes its other functions such as the judicial, executive, and legislative branches. All these actors are responsible for supporting or allowing a particular policy by the global order to continue to harm and create injustice on the poor. Examples of these include the borrowing resource privilege which, for Pogge as well as other authors, shows and promotes the persistence of poverty by supporting the persistence of factors at the local level. This particular policy supports dictators in continuing their corrupt practices that are creating and aggravating poverty conditions. ${ }^{17}$

However, while Pogge is proposing a universal recognition of human rights, he is minimalist in conceiving a correlative duty. This means that while he ascribes to all human beings the right to a quality of life, he is minimalist

${ }^{15} \mathrm{Ibid}, 53$.

${ }^{16} \mathrm{Ibid}, 56-57$

${ }^{17} \mathrm{Ibid}, 59$. An empirical basis of this is also presented by Dambisa Moyo in Dead Aid: Why aid is not working and how there is a better way for Africa (New York: Farrar, Straus, and Giroux, 2009), 3-70, where she extensively discussed poverty in Africa and her analysis of the roots of the problem.

(c) 2017 lan Clark R. Parcon

http://www.kritike.org/journal/issue 20/parcon june2017.pdf

ISSN 1908-7330 


\section{LIMITS OF NEGATIVE DUTY}

in ascribing duty or responsibility to those responsible for the creation of injustice and for responding to this injustice. He is ascribing the duty to those who are primarily responsible, that is, the government and citizens of affluent countries. Furthermore, his claim is that this set of duties should be conceived in negative terms as negative duties, which are opposed to the positive ones. In here, Pogge is trying to deal with the tension between the Libertarians, who are proposing a minimal set of negative duties that simply means a freedom from harm, as opposed to the maximalist that promotes not just self-restraint but active effort to fulfill human rights. This maximalist proposition is often put forward by human rights advocates or those involved in provision of aid. The aid and relief strategy can be considered as a response based on positive duties. Positive duties are also upheld by ideologies that are socialist and communist in orientation. ${ }^{18}$

For Pogge, his institutional approach transcends the language and terminologies of the libertarian and the maximalist. This is because he conceives negative duty also in institutional terms, which also ensures meeting the justice demand. It is not limited to the conventional understanding of negative duty that is just non-interference, which seems to limit the libertarian argument. He also pointed out that in the United States, most especially, citizens are not amenable to positive duties insofar as active intervention would lead to lessening of their economic opportunities and drastic change in their lifestyle. It is for this reason of acceptability at a wider scale that Pogge would ground his proposition on a negative duty rather than positive duty. This means that what is demanded of the governments and citizens of affluent countries are minimal or what he would consider as noncontroversial. It is something that is expected of them and would not demand a Herculean effort or a great amount of sacrifice. It is, in other words, a minimal demand of responsibility. Thus, his proposal also transcends the lack of extensive acceptability that faces the maximalist position. ${ }^{19}$

Moreover, consistent with his Rawlsian background, Pogge would also propose that this negative-duty approach is institutional rather than interactional. Going back to our distinction between interactional and institutional analysis earlier, Pogge puts a primary ascription and blame of the persistence and existence of poverty on global institutions without necessarily removing the responsibility from state actors and even citizens. The primary reason for the realization of justice is altering the institution or its rules and not the conduct and behavior of individuals or groups. ${ }^{20}$

Consistent with his institutional analysis, Pogge would also point to the sense of growing interdependence as crucial in understanding what he

\footnotetext{
18 Pogge, World Poverty and Human Rights, 64-67, Politics as Usual, 27-30.

19 Pogge, World Poverty and Human Rights, 64-65.

${ }^{20} \mathrm{Ibid}, 65$.
}

(C) 2017 lan Clark R. Parcon

http://www.kritike.org/journal/issue 20/parcon june2017.pdf

ISSN 1908-7330

(c) $\mathrm{BY}-\mathrm{NC}-\mathrm{ND}$ 
would refer to as synergestic harm. Synergestic harm is understood as a greater harm that can only be felt in the combination of factors. In the context of global poverty, it is important to point to the growing sense of interdependence, for the factors at the local level can be aggravated by the factors at the international level. This is again illustrated by the example of borrowing resource privilege, where the existence of poverty due to corrupt dictators is worsened by their capacity to borrow money without a check and balance as to how they spend this money. Mostly it is spent to support their stay in power and therefore the continued and worsened existence of poverty. ${ }^{21}$

Furthermore, Pogge's institutional approach promises greater effect with minor changes. This means that minor change in the rules of the global order, which will also have minimal effect on the citizens of affluent countries, can have a significant effect in lowering poverty levels at the global scale. This is also due to the sense of negative duty, which does not demand so much from the citizens of affluent countries. Because of this minimal demand, then, this proposition will have a greater degree of acceptability and greater applicability. ${ }^{22}$

Pogge, thus, would consider his institutional analysis, which points to the problem and solution at the global level that entail alteration of the rules of the global order and ascription of rights to all human beings but negative duties to affluent countries, as creating the conditions for global reform where solution for the poverty problem can be achieved. This, he points, is superior to the positive-duty proposition.

\section{The Inevitability of Positive Duties}

While many hailed Pogge's institutional proposal as pivotal in the discourse on global justice, it has also elicited reactions from various critics. One of the primary criticisms is the question with regard to Pogge's proposal to morally ground his global justice argument on a minimal negative duty. Rowan Cruft, in particular, questions Pogge's human rights proposal if it can be solidly defended without correlative positive duties because, for him, positive human rights need corresponding positive duties. Cruft claims that Pogge's proposal cannot avoid the recognition of a derivative positive duty. This sentiment is also shared by Kok-Chor Tan and Neera Chandhoke. Both of them assert that it seems as if there is more to Pogge's proposal than negative duties. Both claim that grounding Pogge's institutional approach on negative duties alone will be insufficient. I will also discuss the proposal from

\footnotetext{
${ }^{21}$ Pogge, Politics as Usual, 46-50.

22 Ibid, 26-31.
} 
Simon Caney, who actively proposes the inevitability of positive duties in dealing with the issue of global poverty. He would, however, show that Pogge's proposal does not necessarily discount this possibility.

\section{A. Negative and Correlative Duties}

Cruft directly questions Pogge's proposal in the context of properly understanding negative and positive duties. He contends that often negative and positive duties have to be understood first in the context of negative and positive rights. Negative rights are often rights of non-interference or freedom from harm while positive rights are rights to assistance. Although Pogge recognizes that rights can possibly be stated and defended in positive terms, he contends that duties should only be in the negative. ${ }^{23}$

In further analyzing Pogge's proposal, however, Cruft would show that even negative rights entail positive duties. He illustrated it by showing that negative rights would even entail derivative duties that include remedial duties that include duties to offer compensation and reparation for rights violation. Another duty is the duty to stop, and still another is the precautionary duty that means making sure that no amount of harm or injustice will happen in the future. These remedial duties are examples of duties of assistance. However, what is being pointed out here is that negative rights cannot avoid the idea that it entails positive duties both of noninterference and even assistance. ${ }^{24}$

Furthermore, the negative right also entails a fourth derivative duty, which is other-directed precautionary duty, which refers to duties to take action so that other people comply with the idea that no harm should be undertaken. This means that, in the context of global justice, the act of making people comply with the demands of global justice entails positive duties and not mere negative duties alone. As Cruft would clearly state: "Pogge's claims that human rights entail only negative duties can be read as denying that human rights ever entail other-directed precautionary duties." 25

What Cruft would show is that Pogge's negative-duty proposal would mean that it's a denial that other people have to comply with the duty not to harm. It would simply mean that I only check myself if I ever comply with the principle of non-interference. If this is the case, then it makes Pogge's proposal unattractive to serve the purpose of arguing for an institutional

${ }^{23}$ Rowan Cruft, "Human Rights and Positive Duties" in Ethics and International Affairs, 19:1 (2006): 29-37.

${ }^{24}$ Ibid, 29-34.

${ }^{25} \mathrm{Ibid}, 32$.

(c) 2017 lan Clark R. Parcon

http://www.kritike.org/journal/issue 20/parcon june2017.pdf

ISSN 1908-7330

(c) BY-NC-ND 
global justice proposal since it cannot demand responsibility from the affluent. It gives them an incentive to opt out. ${ }^{26}$

Cruft would also show that what Pogge is referring to is the individual aspect of rights and duties. Given this individual reference then, the individual definitely has other features that deserve protection and this can be attained both by duty of protection and duty of non-interference. This goes back to the claim made by Cruft in the earlier part his paper that rights have to be grounded on a person's needs and interests. If this is the case, then the duty that should meet these rights that responds to basic interests is not just non-interference but assistance as well. ${ }^{27}$ This is where the inevitability of positive duties comes in.

Tan is another one who questions Pogge's proposal if it can stand the ground of critique without invoking positive duties in the face of the need to restructure the global order in the light of existing prevalence of poverty at the global scale. He would question the proposal of Pogge that seems to be much indebted to the libertarian position. Pogge is so engrossed in responding to the Libertarians. In the process, however, he is alienating defenders and promoters of human rights, who are actively campaigning for more direct assistance and positive duty-based approach. Pogge seems to run against the tide of the human rights revolution. In fact, Tan would point out that Pogge might have treaded a mistaken path by ascribing to libertarians when, in fact, the latter position is devoid of any possibility of fully defending human rights. Tan further argues that there seems to be more than just negative duty needed to compel the rich to cooperate. There needs to be a more morally binding basis for universal claims of human rights that is not only binding on the rights level but also in the level of duties. Like rights, duties should be universally implemented. ${ }^{28}$

Furthermore, Tan challenges Pogge's notion of harm. He showed that Pogge's notion does not seem to show that the global poor are really harmed. What he simply showed is that they are disadvantaged. Being disadvantaged, however, is not equivalent to harm. Thus, there is no serious claim for injustice. This illustration by Tan showed that Pogge's negative duty proposal and the inability to provide clear arguments for harm make Pogge's position unable to demand from the rich to be responsible for the poor. This makes the demand for global justice untenable. ${ }^{29}$

Chandhoke also shares the sentiment of Tan that like human rights, duties should also be universally embraced. The idea of culpability that

\footnotetext{
${ }^{26}$ Ibid, 34-36.

${ }^{27}$ Ibid, 29-37.

${ }^{28}$ Kok-Chor Tan, "Rights, Harm and Institutions" in Thomas Pogge and His Critics, ed. by Allison Jaggar (Cambridge: Polity Press, 2010), 46-65.

${ }^{29} \mathrm{Ibid}$.
}

(C) 2017 lan Clark R. Parcon

http://www.kritike.org/journal/issue 20/parcon june2017.pdf

ISSN 1908-7330 
Pogge invokes, which is directed only to affluent countries, should be complemented by the recognition of the universal duty to address poverty and human rights violation. What is problematic in Pogge, however, as pointed out by Chandhoke, is that by invoking negative duties, Pogge already limits the sets of duties. By arguing for a limited understanding of duty, Pogge seems to run contrary to the demands of cosmopolitan justice. ${ }^{30}$

Chandhoke also reads Pogge as a liberal philosopher, therefore, the tendency to dismiss any Marxist proposal. However, in the process, he disregards interventions that can be construed as direct and as radically changing the system. While Pogge agrees with Marxists on the causes of world poverty, he is non-receptive to the idea that the persistence of capitalism for example is the primary reason and therefore a radical change in the system is needed for global justice to be attained and global poverty solved. ${ }^{31}$ Cases provided by Chandhoke would show that positive duties are what drive activists to undertake protests that lead to institutional reforms.

\section{B. The Case for Positive Duties}

The case for positive duties was well argued for by Simon Carney. He argued that Pogge's institutional approach that morally demands negative duties has a strength that transcends the limits of explanatory nationalism. Invoking Pogge, Carney argues that the institutional approach has a strength that can demand justice as opposed to explanatory nationalism whose basis is belongingness to the same culture or religion. This limited basis is not necessarily a demand of justice but more a demand of charity. ${ }^{32}$

However, Carney argues that negative duties alone cannot fully account for a comprehensive theory of global justice and on the practical side cannot account for the full eradication of poverty. Not unless there is the claim for positive duty can negative duty fully address the problems of global poverty. ${ }^{33}$

Carney criticizes the wholly institutional approach associated with Pogge in that it is simply limited to those who share in the same institutional scheme. If this is the case, it falls prey to a non-binding moral theory in that those who are not included in the institutional scheme have no moral demand and those who are affluent have the tendency to opt out and therefore justice

\footnotetext{
${ }^{30}$ Neera Chandhoke, "How much is enough, Mr. Thomas? How much will ever be enough?" in Thomas Pogge and His Critics, ed. by Allison Jaggar (Cambridge: Polity Press, 2010), 66-83.

${ }^{31} \mathrm{Ibid}$.

32 Simon Carney, "Global Poverty and Human Rights: The Case for Positive Duties" in Freedom from poverty as a human right: who owes what to the very poor, ed. by Thomas Pogge (New York: Oxford University Press, 2007), 275 - 302.

${ }^{33} \mathrm{Ibid}$.

(c) 2017 lan Clark R. Parcon

http://www.kritike.org/journal/issue 20/parcon june2017.pdf

ISSN 1908-7330
}

(c) BY-NC-ND 
cannot be demanded of them. Carney refers to this a way of penalizing people by way of birth, and it also brings out problems of malign incentives. ${ }^{34}$

The idea of penalizing people by virtue of birth means people who are not included in the scheme of institutional cooperation may not benefit from this approach. In other words, they are excluded simply because their place in the social lottery marginalizes them insofar as they are excluded from this scheme. This places the poor in an unfavorable situation. The idea of malign incentives, on the other hand, means that those not included in the scheme of cooperation have greater incentive to opt out. This means that those who are affluent are given incentive not to participate or own responsibility simply because they do not belong to the global scheme of cooperation. ${ }^{35}$

Carney, however, is clear that Pogge does not deny positive duty. He shows that Pogge's institutional approach should include demand for positive duties so as to provide a comprehensive understanding of global justice that can fully respond to problems of global poverty. He clearly states his position as a hybrid position between the wholly institutional approach and explanatory nationalism. He clearly stated this as

... the Hybrid Account (the General Version): this maintains that (a) persons have a negative duty of justice not to foist an unjust global order on other persons (the institutional component); and (b) persons have a positive duty of justice to eradicate poverty that does not arise from the imposition of an unjust global order (the interactional approach). ${ }^{36}$

This hybrid position also accounts for interactional aspect in that global poverty and injustice have to take into consideration the other aspects that Pogge mentioned but did not pursue. These include local factors within the state that include presence of corrupt dictator, limitations in natural resources, and lack of capacities among others. This part is what is missing in Pogge's account as illustrated by Caney but is essential in analyzing causes of poverty and responding to it comprehensively. ${ }^{37}$

\footnotetext{
${ }^{34} \mathrm{Ibid}$.

${ }^{35} \mathrm{Ibid}$.

${ }^{36} \mathrm{Ibid}, 288$.

${ }^{37} \mathrm{Ibid}, 275-302$.
} 


\section{Critical Evaluation}

The exposition of Pogge's understanding of global justice and the critiques to his proposal give us an opportunity to understand global justice in more comprehensive terms. The need for comprehensibility is not just to meet the criteria of theory but also to make it more responsive and realistic. A more strategic framework that is promoted by Pogge may work for a particular period and respond to a particular aspect, but definitely, it is insufficient to respond to the overwhelming need of global poverty. This proposal, however, would entail a more faithful reading of Pogge, which some of his critics failed to fully appreciate. However, consistent with our search for comprehensive framework, I have shown the limits in Pogge's theory. This is not to show that his theory is a dead end but simply to illustrate that some aspects in his theory might be underdeveloped.

Pogge's responses to his critics illustrate how particular aspects in his work are either misunderstood or underdeveloped. First, he showed constantly in his responses to Tan and Chandhoke that he is clearly not eliminating positive duty. The reason why he would ground his argument on negative duty is for strategic purposes. This is because, as stated earlier, he would like his theory to meet the criterion of feasibility, that is, it can be acceptable to as wide audience as possible. The fact that the demand of responsibility is on the affluent countries and many affluent countries are unable to embrace positive duties, then coming up with a defense of negative duty is more feasible. Pogge would also be wary of additional argument supporting positive duty since this argument has already been raised and defended by numerous authors. Different philosophers have argued for positive duties but problems of global poverty persist. ${ }^{38}$ Pogge must have seen that it's high time to undertake a different strategy.

It is clear that what Pogge proposes in his negative duty-based institutional approach is simply a strategy. However, in missing out on positive duty, Pogge is either guilty of throwing the baby out with the bathwater by focusing on one and disregarding the other aspects or, at the very least, is blind in his inability to fully elaborate an aspect of his theory. I would argue, then, in complementing Pogge's proposal that his notion of negative duty is not an end in the argument of global justice. Negative duty is only a strategic aspect of his theory. However, just like his critics, I argue that his theory may be incomplete unless it is able to elaborate the place of positive duties as complement to negative duties. I also agree with Pogge that

38 Thomas Pogge, "Response to the Critics" in Thomas Pogge and His Critics, ed. by Allison Jaggar (Cambridge: Polity Press, 2010), 175-238.

(c) 2017 lan Clark R. Parcon

http://www.kritike.org/journal/issue 20/parcon june2017.pdf

ISSN 1908-7330

(c) $)$ BY-NC-ND 
negative duties have a greater role but positive duties need not be fully eliminated from the picture.

The second cluster of critique constitutes a misreading of his notion of duty where negative duty is grounded. Cruft, Tan, and Chandhoke seem to equate Pogge's proposal of duty to the traditional notion of rights-harmduty interrelationship. This traditional notion shows direct causal relation that rights are violated when harm is done; therefore, a corresponding duty is demanded. In the context of global justice, a sense of direct causality should also be established to illustrate that harm is committed to the global poor, which constitutes a violation of their rights, thus, entailing positive duties to correct this harm. Moreover, the understanding of negative duty does not limit it to mere avoidance alone but also includes a more positive intervention that can prevent from further harming the global poor.

As a response to this, Pogge is clear that he is not just referring to harm alone when he talks about global injustice. The strength of the institutional approach is in showing that social justice should be included, which his critics have missed out. Pogge specifically states that:

To be sure, this conclusion does not flow from my account of institutional harming alone (which by itself, as we have seen, is quite inconclusive). It follows from this account of harm plus a specific account of social justice: only if foreseeably and avoidably producing certain large socioeconomic inequalities renders a global institutional order unjust can contributing to its design or imposition be an instance of harming. ${ }^{39}$

Furthermore, Pogge also showed that negative duty is illustrated here in that the changes in the institutional structure of the global order are needed to prevent harming the global poor.

Finally, Pogge made it clear that he also was remiss especially in disregarding the interactional aspect of his theory. He apologized for this especially in his response to Cruft. ${ }^{40}$ Again, this shows that Pogge might have been guilty of throwing the baby out with the bathwater by way of oversimplification or, upon second look, he recognized that some aspect of his work is not headed in the right direction. This recognition, then, constitutes an important part in the development of a theory of global justice in that similar with Caney's claim, the interactional aspect need not be

${ }^{39} \mathrm{Ibid}, 195$.

40 Thomas Pogge, "Severe Poverty as a violation of negative duties" in Ethics and International Affairs, 19:1 (2006): 55-83.

(C) 2017 lan Clark R. Parcon

http://www.kritike.org/journal/issue 20/parcon june2017.pdf

ISSN 1908-7330 
eliminated for it can account for dealing with causes that cannot be accounted for by the institutional approach. This is where positive duty is greatly needed, that is, to respond to the limits of negative duty-based institutional approach.

However, a more faithful understanding of Pogge's work, which includes the underdeveloped aspect of his theory, was presented by Jiwei $\mathrm{Ci}$. Ci contends that while Pogge claims that his theory is noncontroversial in that it only pushes for a negative duty. It is, however, radical in that it challenges the dominant moral mindset of Western society. The dominant moral reasoning in the West is still anchored on interactional analysis that even if included should be considered limited. This analysis gives much room for Westerns to excuse themselves from responsibility in that no direct causality can be attributed to the character and behavior of individuals and groups to the existence of poverty. The institutional approach, then, challenges this mindset by making the affluent morally accountable and primarily morally accountable which demands, at the very least, negative duty so that changes in the global structure can be undertaken. ${ }^{41}$

As a summative way of stating my position, which is parallel to what is being proposed by Caney, negative duty is pivotal in the global justice discourse in that it provides a strategic move for problems of global poverty to be remedied. However, global justice should not do away with positive duties for a more comprehensive response to the poverty problem. A step further than Caney, however, I have shown that Pogge has put forward a more affirmative notion of negative duty in that it also includes institutional reform. It is this proposal that makes global justice inclusive of all, both as rights claimants and duty bearers even if greater demand is expected of those who are affluent.

\section{Conclusion}

This study has shown that the issue of global justice is still very young and is in its development stage. This is illustrated by the fact that Pogge's proposal builds from what is limitedly available, that is, the usual ascription of causes of poverty to national factors, which he refers to as explanatory nationalism. A further development, albeit limited, is provided for by international justice literature. Yet even this account cannot support a comprehensive analysis because it is limited only to state-to-state interaction. The role of other supranational bodies is not well accounted for in their contribution to global poverty. Furthermore, Pogge showed the

${ }^{41}$ Jiwei Ci, "What Negative Duties? Which Moral Universalism?" in Thomas Pogge and His Critics, ed. by Allison Jaggar (Cambridge: Polity Press, 2010), 84-102.

(c) 2017 lan Clark R. Parcon

http://www.kritike.org/journal/issue 20/parcon june2017.pdf

ISSN 1908-7330

(cc) BY-NC-ND 
interdependency of these actors and showed their capacity to effect synergestic harm. This is where the confluence of these various factors creates grave effect on the conditions of the global poor.

The institutional proposal of Pogge, then, shows how the discourse has rendered the previous theoretical discourses insufficient, which requires a new framework of analysis. His proposal also shows its strategic strength, in that, by accounting for the institutional approach in the negative duty, it can have greater acceptability. However, it also shows that some loopholes are present, in that, this notion can be misunderstood as referring to harm alone without the social justice aspect. Furthermore, it has shown that despite the comprehensive strength of negative duty, it cannot do away with positive duty because there are reasons for global poverty beyond the negative dutybased institutional approach.

What is not fully elaborated, then, is the aspect in Pogge's work, which shows the reimagining of negative duties to include institutional changes. Another is the aspect in his work, which does not include interactional aspect. The interactional aspect is what can account for the other reasons for global poverty. By pursuing these aspects further and further elaborating them, global justice can hopefully be demanded of and for all.

\section{Philosophy Department, Ateneo de Davao University, Philippines}

\section{References}

Carney, Simon, "Global Poverty and Human Rights: The Case for Positive Duties" in Freedom from Poverty As A Human Right: Who Owes What To The Very Poor, ed. by Thomas Pogge (New York: Oxford University Press, 2007).

Chandhoke, Neera, "How Much Is Enough, Mr. Thomas? How Much Will Ever Be Enough?" in Thomas Pogge and His Critics, ed. by Allison Jaggar (Cambridge: Polity Press, 2010).

Ci, Jiwei, "What Negative Duties? Which Moral Universalism?" in Thomas Pogge and His Critics, ed. by Allison Jaggar (Cambridge: Polity Press, 2010).

Cruft, Rowan, "Human Rights and Positive Duties" in Ethics and International Affairs, 19:1(2006).

Moyo, Dambisa, Dead Aid: Why Aid Is Not Working and How There Is a Better Way for Africa (New York: Farrar, Straus, and Giroux, 2009).

Pogge, Thomas, Politics as Usual: What Lies behind the Pro-Poor Rhetoric (Cambridge: Polity Press, 2010).

"Rawls on International Justice" in The Philosophical Quarterly, 51:203 (2001).

(C) 2017 lan Clark R. Parcon

http://www.kritike.org/journal/issue 20/parcon june2017.pdf

ISSN 1908-7330 


\section{LIMITS OF NEGATIVE DUTY}

"Response to the Critics" in Thomas Pogge and His Critics, ed. by Allison Jaggar (Cambridge: Polity Press, 2010).

"Severe Poverty as a Violation of Negative Duties" in Ethics and International Affairs, 19:1 (2006).

World Poverty and Human Rights: Cosmopolitan Responsibilities and Reform (Cambridge: Polity Press, 2002).

Rawls, John, The Law of Peoples (Massachusetts: Harvard University Press, 1999).

Theory of Justice (Massachusetts: Harvard University Press, 1971).

Tan, Kok-Chor, "Rights, Harm and Institutions" in Thomas Pogge and His Critics, ed. by Allison Jaggar (Cambridge: Polity Press, 2010). 